\title{
PENGGUNAAN Phanerochaete chrysosporium PADA PENGOLAHAN PULP BIO-SEMI-MEKANIS KAYU TERENTANG (Campnosperma auriculata Hook.f)*
}

\section{(Application of Phanerochaete chrysosporium on Biochemimechanical Pulping Process of Terentang Wood (Campnosperma auriculata Hook.f))}

\author{
Yeni Aprianis ${ }^{1}$, Denny Irawati ${ }^{2}, \&$ Sri Nugroho Marsoem ${ }^{2}$ \\ ${ }^{1}$ Balai Penelitian Teknologi Serat Tanaman Hutan, Jl. Raya Bangkinang-Kuok, Km. 9, Bangkinang, Riau \\ ${ }^{2}$ Jurusan Teknologi Hasil Hutan, Fakultas Kehutanan, Universitas Gadjah Mada \\ Jl. Agro No. 1, Bulaksumur, Yogyakarta \\ E-mail: yennie_dy@yahoo.co.id
}

Diterima 13 Agustus 2015, Direvisi 22 April 2016, Disetujui 16 Agustus 2016

\begin{abstract}
Terentang wood (Campnosperma auriculata Hook.f) is relatively low in specific gravity (0.3), bence its utilization as pulp by chemi-mechanical is an alternative process. Energy consumption was reduced by applying lignin

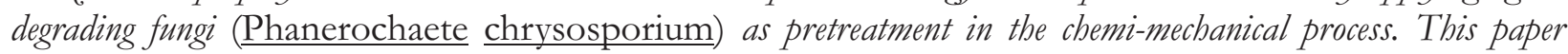
examines the effects of $\underline{\mathrm{P}}$. chrysosporium incubation periods into chemical components and energy refining consumption of terentang wood. Fourpercent of $\mathrm{NaOH}$ was used in the chemi-mechanical process, and incubation periods studied were

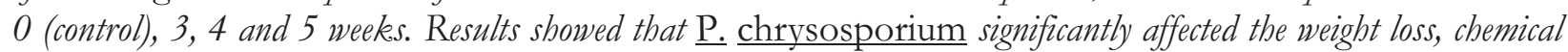
properties, and refining energy consumption of terentang wood pulping process. Wood chip weight loss was about 15.95$21.31 \%$ and alpha-cellulose raised up to $6.77 \%$. Five weeks incubation time decreased lignin content up to $22.97 \%$ and saved the refining energy up to $22.7 \%$.
\end{abstract}

Keywords: Incubation period, Phanerochaete chrysosporium, biopulping, terentang

\begin{abstract}
ABSTRAK
Kayu terentang (Campnosperma auriculata Hook.f) memiliki berat jenis rendah (0,3), sehingga salah satu alternatif pemanfaatannya menjadi pulp adalah dengan proses semi-mekanis. Pengurangan konsumsi energi pada proses kimia-mekanis dilakukan menggunakan jamur pendegradasi lignin (Phanerochaete chrysosporium) sebagai perlakuan awal. Pengolahan pulp semi-mekanis menggunakan $\mathrm{NaOH} 4 \%$ dan masa inkubasi 0 (kontrol), 3, 4, dan 5 minggu. Hasil penelitian menunjukkan bahwa perlakuan $P$. chrysosporium berpengaruh nyata terhadap kehilangan berat, kandungan kimia, dan kebutuhan energi refining. Kehilangan berat serpih kayu berkisar 15,95-21,31\% dan peningkatan kadar selulosa mencapai 6,77\%. Inkubasi selama lima minggu menurunkan kadar lignin hingga 22,97\% dan menghemat energi refining sebesar $22,7 \%$.
\end{abstract}

Kata kunci: Lama inkubasi, Phanerochaete chrysosporium, biopulping, terentang,

\section{PENDAHULUAN}

Secara umum, kayu dengan berat jenis rendah lebih cocok digunakan sebagai bahan baku pulp semi-mekanis karena penguraian seratnya (refining) lebih mudah (Cameron, 2004). Kayu terentang memiliki berat jenis 0,30 lebih rendah dari berat jenis kayu mangium 0,69. Jika proses pulping kayu

\footnotetext{
*) Bagian dari tesis Magister of Science pada Fakultas Kehutanan, UGM, 2015
} 
mangium tergolong mudah, berdasarkan perbedaan berat jenisnya, maka kayu terentang akan lebih mudah dalam proses pulpingnya (Raphy, Anoop, Aruna, Sheena, \& Ajayghosh, 2011).

Pengolahan pulp semi-mekanis merupakan kombinasi perlakuan kimia ringan dan proses mekanis. Kelemahan dari proses kimia-mekanis ini adalah penggunaan energi yang cukup tinggi untuk proses refining. Salah satu cara mengurangi kebutuhan energi pada pengolahan pulp semimekanis adalah dengan memberi perlakuan awal menggunakan jamur pendegradasi lignin (biopulping) sebelum pemasakan. Perlakuan jamur dapat mengurangi kebutuhan energi refining dan penggilingan pada kayu spruce sebesar 30\% dan kayu Carpinus betulus sebesar 43\% (Scott, Akhtar, Swaney, \& Houtman, 2002; Kasmani, Talaeipour, Hemmasi, Mahdavi, \& Samariha, 2012).

Proses biopulping biasanya dilakukan dengan menggunakan jamur pendegradasi lignin seperti Phanerochaete chrysosporium (Kasmani et al., 2012) dan Ceriporiopsis subvermispora (Ferraz, Parra, Freer, Baeza, \& Rodriquez, 2000). Jamur P. chrysosporium lebih banyak menyerang jenis kayu daun lebar, sedangkan $C$. subvermispora lebih banyak menyerang kayu daun jarum, sehingga proses biopulping kayu daun lebar disarankan menggunakan P. chrysosporium (Ferraz et al., 2000). Selain itu, P. chrysosporium memiliki kemampuan hidup pada kisaran suhu yang lebar yaitu $25-40^{\circ} \mathrm{C}$ (Singh \& Chen, 2008; Kasmani et al., 2012).

Berdasarkan hasil penelitian sebelumnya, lama inkubasi jamur pada proses biopulping biasanya adalah 1-16 minggu (Mendonca, Ferraz, Kordaschia, \& Koch, 2004; Pujirahayu \& Marsoem, 2006; Yang, Zhan, Wang, \& Fu, 2008; Istikowati \& Marsoem, 2009; Husaini et al., 2011; Kasmani et al., 2012). Proses biodegradasi kayu dalam proses biopulping merupakan fungsi dari lama waktu inkubasi (Ferraz et al., 2000; Hataka \& Hammel, 2010). Semakin lama waktu inkubasi, semakin baik hasil biopulpingnya, seperti proses biopulping kayu randu (Ceiba pentandra) dilaporkan memerlukan waktu inkubasi jamur P. chrysosporium optimal 40 hari untuk lignin terdegradasi, sehingga kadar ligninnya berkurang sebesar 12,34\% (Istikowati \& Marsoem, 2009). Tulisan ini mempelajari penggunaan jamur $P$. chrysosporium terhadap kehilangan berat, perubahan kandungan kimia, dan kebutuhan energi refining pada pulp semi-mekanis kayu terentang.

\section{BAHAN DAN METODE}

\section{A. Bahan dan Alat}

Bahan baku yang digunakan adalah kayu terentang yang berasal dari Kabupaten Kuantan Singingi, Provinsi Riau, sebanyak tiga pohon sebagai ulangan. Isolat jamur P. chrysosporium American Type Culture Collection (ATCC) 34541 diperoleh dari Laboratorium Mikrobiologi, Pusat Antar Universitas (PAU), Universitas Gadjah Mada (UGM) untuk perlakuan biopulping. Bahan kimia untuk analisa kimia kayu, antara lain: asam sulfat $\left(\mathrm{H}_{2} \mathrm{SO}_{4}\right)$, asam asetat glasial $\left(\mathrm{CH}_{3} \mathrm{COOH}\right)$, etanol $\left(\mathrm{C}_{2} \mathrm{H}_{5} \mathrm{OH}\right)$, natrium klorida $\left(\mathrm{NaClO}_{2}\right)$, $\mathrm{NaOH}$, aseton $\left(\mathrm{CH}_{3} \mathrm{COCH}_{3}\right)$ teknis, dan aquades. Bahan kimia untuk pengolahan pulp semimekanis menggunakan $\mathrm{NaOH} 4 \%$. Disk refiner (KRK seri 0407064) digunakan untuk menggiling pulp sebagai perlakuan mekanis.

\section{B. Metode Penelitian}

Persiapan bahan baku diawali dengan pembuatan serpih berukuran $2 \mathrm{~cm} \times 2 \mathrm{~cm} \times 0,2$ $\mathrm{cm}$, kemudian diukur kadar airnya. Sebanyak $200 \mathrm{~g}$ BKT (Berat Kering Tanur) serpih terentang dimasukkan ke dalam plastik dan direndam dengan air selama 16 jam, kemudian ditiriskan. Serpih yang telah direndam selanjutnya disterilisasi menggunakan autoclave pada suhu $121^{\circ} \mathrm{C}$ selama 30 menit (Mendonca et al., 2004).

Persiapan suspensi jamur diawali dengan perbanyakan jamur $P$. chrysosporium menggunakan media PDA sebanyak 30 tabung reaksi, kemudian ditempatkan pada inkubator bersuhu $27^{\circ} \mathrm{C}$ selama 7 hari. Pengambilan miselia pada setiap tabung reaksi dilakukan dengan menambahkan $15 \mathrm{~mL}$ aquades steril yang mengandung dextrose $1 \%$, kemudian dikocok agar media terpisah. Suspensi miselia yang digunakan untuk mendegradasi kayu terlebih dahulu dihitung koloni spora menggunakan hemacytometer. Jumlah spora pada penelitian ini adalah 1,70 x $10^{9}$ spora $/ \mathrm{mL}$. Sebanyak $10 \mathrm{~mL}$ suspensi miselia yang mengandung dextrose 1\% dimasukkan pada serpih steril, kemudian diinkubasi selama 3, 4, dan 5 minggu. Pemilihan waktu inkubasi tersebut berdasarkan uji pendahuluan, dimana inkubasi 3-5 minggu menunjukkan pertumbuhan jamur sudah mulai merata (Gambar 1). Sebanyak $3 \mathrm{~g}$ serpih inokulasi ditentukan kadar airnya, kemudian 
diperoleh Berat Kering Tanur (BKT) setelah inokulasi dan dihitung kehilangan berat sesuai Persamaan 1. Serpih tanpa suspensi jamur merupakan serpih kontrol.

Kehilangan berat $(\%)=\frac{\mathrm{W} 1-\mathrm{W} 2}{\mathrm{~W} 1} \times 100 \%$

Keterangan (Remarks):

W1 = berat kering tanur sebelum inokulasi jamur W2 = berat kering tanur setelah inokulasi jamur

Serpih perlakuan dan kontrol dianalisa kandungan kimianya. Analisa kadar lignin Klason berdasarkan SNI 0492 (2008), kadar holoselulosa mengacu pada metode Browning (1967), kadar $\alpha$ selulosa sesuai pengujian dalam SNI 01-1309 (1989), dan penentuan hemiselulosa merupakan perhitungan selisih holoselulosa dengan $\alpha$-selulosa.

Pengolahan pulp semi-mekanis diawali dengan serpih perlakuan dan kontrol sebanyak $100 \mathrm{~g}$ direndam menggunakan $\mathrm{NaOH} 4 \%$ (1:10) selama 15 menit, kemudian dimasak menggunakan rotary digester pada suhu $120^{\circ} \mathrm{C}$ selama 30 menit. Serpih dicuci dan diuraikan seratnya menggunakan disk refiner. Refining dilakukan sebanyak dua kali penggilingan (Haroen, 2008; Bierman, 1996). Selama proses refining dicatat waktu yang dibutuhkan, untuk menghitung kebutuhan energi sesuai dengan Persamaan (2) (Johansson, 2011).

\section{Analisis Data}

Semua perlakuan dan pengujian diulang sebanyak 3 kali, kemudian data yang diperoleh dianalisis varian dan jika berbeda nyata dilanjutkan dengan uji Tukey-HSD (Honestly significant difference) pada taraf 5\%.

Keterangan:

$$
\mathrm{K}=\frac{\mathrm{Pxt}}{\mathrm{m}}
$$

$\mathrm{K}=$ Konsumsi energi refining spesifik (kWh/ton)

$\mathrm{P}=$ kekuatan refiner $(\mathrm{kW})=0,2 \mathrm{~kW}$

$\mathrm{t}=\operatorname{waktu}(\mathrm{jam})$

$\mathrm{m}=$ berat serpih $=100 \mathrm{~g}=10^{-4}$ ton .

\section{HASIL DAN PEMBAHASAN}

\section{A. Kehilangan Berat}

Rerata persentase kehilangan berat serpih terentang selama inkubasi 3, 4, dan 5 minggu dapat dilihat pada Tabel 1. Rerata kehilangan berat serpih terentang pada lama inkubasi 3 minggu menunjukkan nilai yang berbeda dengan lama inkubasi 4 dan 5 minggu, namun lama inkubasi 4 minggu mempunyai nilai yang sama dengan 5 minggu. Lama inkubasi mempunyai hubungan positif dengan kehilangan berat. Semakin lama inkubasi maka semakin banyak kehilangan berat serpih terentang. Hal ini menandakan semakin banyak komponen kimia kayu yang terdegradasi. Komponen kimia kayu yang terdegradasi oleh beberapa jamur busuk putih adalah senyawa lignin dan hemiselulosa (Istek, Sivrikaya, Eroglu, \& Gulsoy, 2005).

Kehilangan berat pada lama inkubasi 3, 4, dan 5 minggu berturut-turut adalah 15,95; 20,29; dan 21,31\% (Tabel 1). Lama inkubasi 4 dan 5 minggu mempunyai kehilangan berat yang lebih besar

Tabel 1. Rerata kehilangan berat serpih terentang setelah inokulasi $P$. chrysosporium $(\mathrm{n}=3)$ Table 1. The average weight loss after $\underline{\mathrm{P}} . \underline{\text { chrysosporium inoculation }(n=3)}$

Lama inkubasi (minggu)

Period of incubation (weeks)

Berat awal
(Initial weight, g)

Berat akhir
(Final weight, g)

Kehilangan berat

(Weight loss, \%)

\begin{tabular}{cccc}
\hline 3 & & 168,11 & $15,95 \pm 0,00^{\mathrm{a}}$ \\
4 & 200 & 159,41 & $20,29 \pm 1,16^{\mathrm{b}}$ \\
5 & & 159,37 & $21,31 \pm 0,22^{\mathrm{b}}$ \\
\hline
\end{tabular}

Keterangan (Remarks) : Angka yang diikuti oleh huruf yang sama tidak berbeda nyata pada uji Tukey p $\leq 0,05$ (Numbers followed by the same letter are non-significantly different, Tukey's test $p \leq 0.05$ ) 


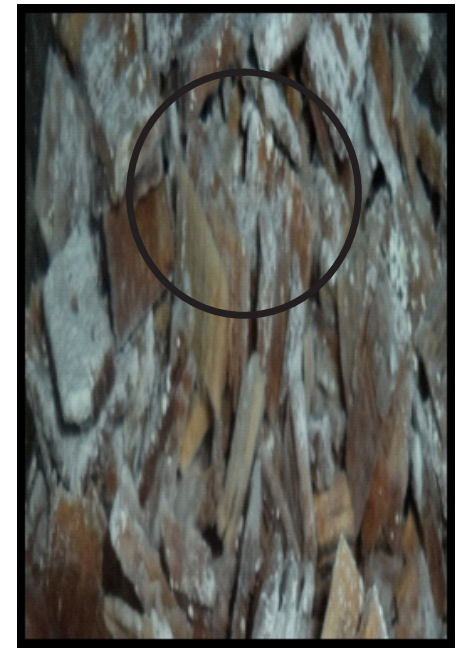

3 minggu

(3weeks)

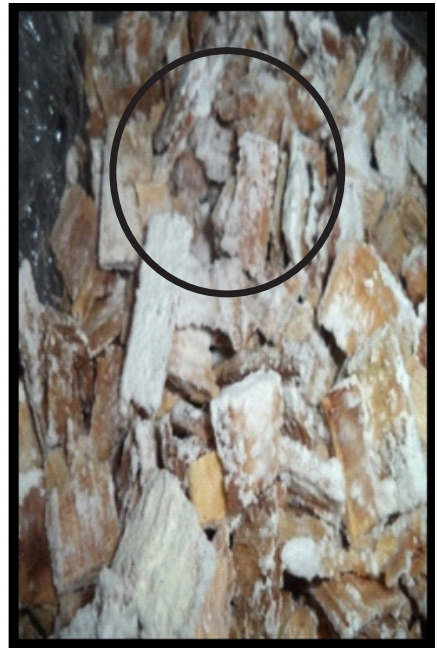

4 minggu

(4 weeks)

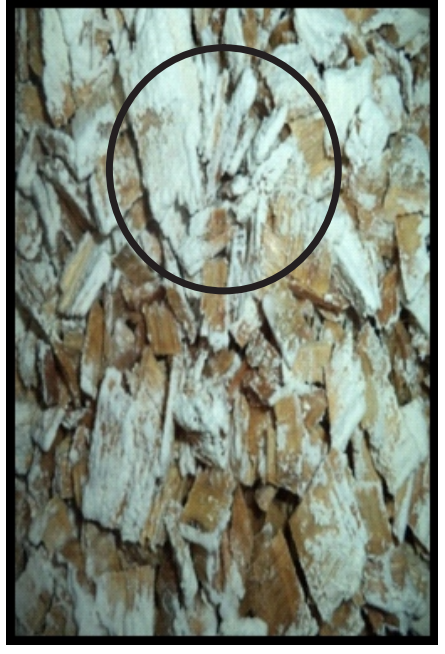

5 minggu

(5 weeks)

Gambar 1. Pertumbuhan miselia P. chrysosporium pada serpih terentang Figure 1. The growth of $\underline{\mathrm{P}}$. chrysosporium mycelia on terentang wood chips

dibandingkan dengan lama inkubasi 3 minggu. Hal ini disebabkan oleh pertumbuhan miselia jamur yang semakin luas dan banyak setelah 4 dan 5 minggu, sehingga aktivitas degradasinya juga semakin tinggi, seperti yang terlihat pada Gambar 1. Menurut Kirk, Richard, dan John (1992) enzim peroksidase (MnP/Mangan peroksidase dan LiP/Lignin Peroksidase) yang berperan dalam proses degradasi lignin disekresikan sebanding dengan pertumbuhan miselia.

Jenis kayu yang berbeda bila diinokulasikan dengan jamur dapat menghasilkan kehilangan berat yang berbeda meskipun jenis jamur yang diinokulasikan adalah sama. Serpih hornbeam (Carpinus betulus) yang diinokulasi jamur $P$. chrysosporium selama 4 minggu memiliki persentase kehilangan berat 18,56\% (Kasmani et al., 2012). Selain hornbeam, kayu jati bagian gubal yang telah diinokulasi jamur P. chrysosporium selama 60 hari mengalami kehilangan berat 10,61\% (Koyani \& Rajput, 2014). Nilai kehilangan berat kedua jenis kayu tersebut lebih kecil dibandingkan dengan kehilangan berat serpih terentang. Hal ini diduga disebabkan oleh perbedaan berat jenis kayu tersebut. Kayu dengan berat jenis rendah memiliki pori yang lebih besar atau lebih banyak dibandingkan kayu dengan berat jenis tinggi. Berat jenis kayu gubal jati dan hornbeam berturut-turut adalah 0,64-0,70 (Pertiwi, 2014) dan 0,45-0,71 (Samariha, 2011), sedangkan berat jenis terentang pada penelitian ini adalah 0,3.

\section{B. Kandungan Kimia Kayu Terentang}

Rerata komponen kimia kayu sebelum dan setelah perlakuan inokulasi dengan jamur $P$. chrysosporium selama 3, 4, dan 5 minggu serta perubahan yang terjadi ditunjukkan pada Tabel 2 dan Tabel 3. Tabel 2 menunjukkan bahwa perlakuan lama inkubasi berpengaruh nyata terhadap kandungan lignin, holoselulosa, $\alpha$-selulosa, dan berpengaruh tidak nyata terhadap hemiselulosa.

Perbandingan kadar $\alpha$-selulosa dengan kadar lignin merupakan perbandingan kadar aktual untuk kedua komponen ini. Serpih yang diberi perlakuan jamur memiliki perbandingan $\alpha$ selulosa terhadap lignin lebih tinggi dibandingkan dengan kontrol. Hal ini menunjukkan bahwa jamur menggunakan lignin yang lebih banyak dibandingkan $\alpha$-selulosa untuk pertumbuhan miselia (Irawati et al., 2012).

Tabel 2 menunjukkan bahwa perlakuan dengan P. chrysosporium mengakibatkan penurunan kadar lignin bila dibandingkan kontrol. Secara statistik kadar lignin serpih terentang setelah perlakuan lama inkubasi 3, 4, dan 5 minggu memiliki nilai yang tidak berbeda nyata. Artinya tidak ada lagi penurunan kadar lignin yang signifikan setelah inkubasi 3 minggu. Hal ini juga terjadi pada kayu 
Tabel 2. Kandungan kimia (\%) dan perbandingan C/L kayu terentang $(\mathrm{n}=3)$

Table 2. The chemical component (\%) and $C / L$ ratio of terentang wood ( $n=3)$

\begin{tabular}{cccccc}
\hline $\begin{array}{l}\text { Lama inkubasi (minggu) } \\
\text { (Incubation period, weeks) }\end{array}$ & $\begin{array}{c}\text { Lignin } \\
(\mathrm{L})\end{array}$ & $\begin{array}{c}\text { Holoselulosa } \\
\text { (Holocellulose })\end{array}$ & $\begin{array}{c}\text { Alfa selulosa } \\
(\text { Alpha cellulose }) \\
(\mathrm{C})\end{array}$ & $\begin{array}{c}\text { Hemiselulosa } \\
(\text { Hemicellulose })\end{array}$ & $\begin{array}{c}\text { Perbandingan } \\
\mathrm{C} / \mathrm{L}(\mathrm{C} / \text { L ratio })\end{array}$ \\
\hline Kontrol/control & $32,71 \pm 1,92^{\mathrm{b}}$ & $81,02 \pm 0,65^{\mathrm{a}}$ & $43,26 \pm 1,06^{\mathrm{a}}$ & $37,6 \pm 2,05^{\mathrm{a}}$ & 1,32 \\
3 & $26,36 \pm 3,61^{\mathrm{a}}$ & $89,70 \pm 6,66^{\mathrm{b}}$ & $46,19 \pm 1,03^{\mathrm{b}}$ & $43,51 \pm 7,67^{\mathrm{a}}$ & 1,75 \\
4 & $25,33 \pm 0,33^{\mathrm{a}}$ & $81,05 \pm 2,26^{\mathrm{a}}$ & $45,28 \pm 0,48^{\mathrm{ab}}$ & $35,76 \pm 2,39^{\mathrm{a}}$ & 1,78 \\
5 & $25,20 \pm 1,53^{\mathrm{a}}$ & $76,94 \pm 0,59^{\mathrm{a}}$ & $44,64 \pm 0,27 \mathrm{ab}$ & $32,31 \pm 0,83^{\mathrm{a}}$ & 1,77 \\
HSD 5\% & 6,66 & 9,27 & 2,06 & - & - \\
\hline
\end{tabular}

Keterangan (Remarks) : Angka yang diikuti oleh huruf yang sama tidak berbeda nyata pada uji Tukey $\mathrm{p} \leq 0,05$ (Numbers followed by the same letter are non-significantly different, Tukey's test $\leq \leq 0.05$ )

Tabel 3. Perubahan komponen kimia setelah inokulasi P. chrysosporium (\%) Table 3. Chemical content change of terentang chips after P. chrysosporium inoculation (\%)

\begin{tabular}{ccccc}
\hline $\begin{array}{c}\text { Lama inkubasi (minggu) } \\
\text { (Incubation period, weeks) }\end{array}$ & Lignin & $\begin{array}{c}\text { Holoselulosa } \\
\text { (Holocellulose) }\end{array}$ & $\begin{array}{c}\text { Alfa selulosa } \\
\text { (Alpha cellulose) }\end{array}$ & $\begin{array}{c}\text { Hemiselulosa } \\
\text { (Hemicellulose) }\end{array}$ \\
\hline 3 & $-19,41$ & $+10,72$ & $+6,77$ & $+15,72$ \\
4 & $-22,56$ & $+0,04$ & $+4,67$ & $-4,89$ \\
5 & $-22,97$ & $-5,03$ & $+3,18$ & $-14,07$ \\
\hline
\end{tabular}

Keterangan (Remarks): tanda minus (negative) $(-)=$ pengurangan persentase kandungan kimia (reduction of chemical content) tanda positif $($ positive $)(+)=$ peningkatan persentase kandungan kimia (increase of chemical content)

Fagus orientalis, dimana kadar lignin tidak lagi mengalami penurunan setelah diinkubasi dengan P. chrysosporium selama lebih dari 20 hari hingga 60 hari (Istek et al., 2005). Fenomena kedua jenis kayu tersebut mengindikasikan bahwa jamur $P$. chrysosporium tidak selektif terhadap lignin di atas inkubasi 20 hari.

Beberapa penelitian terdahulu pada kayu sengon, randu, dan hornbeam yang diinkubasi selama 30 hari dengan jamur $P$. chrysosporium menunjukkan pengurangan kadar lignin yang berbeda. Sengon mengalami pengurangan kadar lignin sebesar 8,20\% (Pujirahayu \& Marsoem, 2006), sedangkan randu mengalami pengurangan kadar lignin sebesar 9,60\% (Istikowati \& Marsoem, 2009), dan hornbeam mengalami pengurangan kadar lignin sebesar 18,56\% (Talaeipour et al., 2010; Kasmani et al., 2012). Nilai degradasi lignin kayu sengon, randu, dan bornbeam lebih kecil bila dibandingkan dengan hasil penelitian ini (Tabel 2 dan Tabel 3).
Kadar holoselulosa kayu terentang setelah diberi perlakuan jamur P. chrysosporium selama 3 minggu berbeda dengan lama inkubasi 4 minggu, sedangkan kadar holoselulosa kayu terentang setelah diberi perlakuan jamur P. chrysosporium selama 4 minggu mempunyai nilai sama dengan 5 minggu dan kontrol (Tabel 2). Hal ini disebabkan karena jamur terlebih dahulu mendegradasi lignin sehingga persentase holoselulosa pada kayu meningkat.

Pada penelitian ini diduga jamur P. chrysosporium ATCC 34541 yang digunakan memiliki sifat simultan dalam mendegradasi dinding sel kayu, yang menyebabkan adanya penurunan kadar holoselulosa. Jamur busuk putih dapat mempunyai pola simultan (non selektif) terhadap degradasi sel, artinya jamur busuk putih selain mendegradasi lignin, juga dapat mendegradasi selulosa dan hemiselulosa (Gamauf, Metz, \& Seiboth, 2007). Selain pola simultan, jamur busuk putih juga memiliki pola yang hanya selektif 
mendegradasi lignin. Pola pembusukan jamur busuk putih adalah tergantung pada strain jamur dan substrat yang digunakan (Gamauf et al., 2007).

Waktu inkubasi yang semakin lama menyebabkan penurunan kadar holoselulosa yang besar, sehingga kadar holoselulosa menjadi semakin rendah (Tabel 2 dan Tabel 3). Setelah inkubasi 3 dan 4 minggu persentase kadar holoselulosa lebih tinggi $0,04-10,72 \%$ dibanding kontrol, namun setelah diinkubasi selama 5 minggu terjadi penurunan kadar holoselulosa sebesar 5,03\%. Hal ini disebabkan jamur mulai mengkonsumsi karbohidrat yang ada pada kayu disaat ketersediaan glukosa $1 \%$ semakin berkurang dengan meningkatnya waktu inkubasi.

Nilai kadar holoselulosa serpih terentang setelah diinkubasi selama 3, 4, dan 5 minggu dengan jamur $P$. chrysosporium berkisar antara 76,94-89,70\%. Hasil penelitian Istikowati dan Marsoem (2009) pada kayu randu yang diinkubasi selama 20, 30, dan 40 hari dengan jamur yang sama mempunyai kadar holoselulosa sebesar $75-76,7 \%$. Nilai kadar holoselulosa serpih terentang lebih besar dibandingkan dengan kayu randu. Hal ini disebabkan oleh perbedaan jenis kayu/substrat yang digunakan dan tingkat keselektifan jamur terhadap lignin.

Persentase kadar $\alpha$-selulosa kontrol (43,26\%) lebih rendah dibandingkan dengan kadar $\alpha$ selulosa setelah diberi perlakuan inkubasi 3 , 4, dan 5 minggu yaitu berturut-turut 46,19\%; 45,28\%; dan 44, 64\%. Tingginya kadar $\alpha$-selulosa pada 3 minggu dikarenakan jamur ini lebih selektif mendegradasi lignin pada inkubasi 3 minggu, sehingga persentase $\alpha$-selulosa meningkat, namun diatas 3 minggu kemampuan mendegradasi lignin berkurang, sehingga jamur memperoleh makanan gula dari selulosa. Tingginya persentase kadar $\alpha$ selulosa merupakan hal yang diinginkan dalam pengerjaan pulp.

Bila dibandingkan dengan penelitian sebelumnya, kayu randu dan sengon yang diberi perlakuan $P$. chrysosporium mengalami penurunan persentase kadar $\alpha$-selulosa (Istikowati \& Marsoem, 2006; Pujirahayu \& Marsoem, 2009). Hal ini diduga disebabkan inokulasi $P$. chrysosporium pada kayu randu dan sengon tanpa adanya penambahan nutrisi glukosa, sehingga pada proses inkubasi selulosa juga ikut terdegradasi. Hasil penelitian Singh dan Chen (2008) menyatakan bahwa dengan penambahan glukosa 1\% (b/v) dapat meningkatkan kinerja enzim lignolitik.

Tabel 2 menunjukkan bahwa perlakuan $P$. chrysosporium berpengaruh tidak nyata terhadap kadar hemiselulosa, walaupun kadar hemiselulosa terentang cenderung menurun sebesar 14,07\% setelah inkubasi selama 5 minggu (Tabel 3). Penurunan kadar hemiselulosa terjadi pada lama inkubasi 4 dan 5 minggu. Hal ini disebabkan pada lama inkubasi tersebut jamur membutuhkan karbohidrat, karena ketersediaan glukosa 1\% semakin berkurang dengan meningkatnya lama inkubasi. Persentase kadar hemiselulosa berpengaruh tidak nyata setelah perlakuan $P$. chrysosporium merupakan sesuatu yang diinginkan dalam pengolahan pulp, artinya hemiselulosa tidak mengalami perubahan dengan adanya perlakuan P. chrysosporium selama 5 minggu. Hemiselulosa berperan pada kekuatan tarik kertas (Fengel \& Wegener, 1995). Penurunan kadar hemiselulosa serpih terentang lebih kecil dibandingkan dengan sengon. Menurut Widjaya et al. (2003) sengon yang diinkubasi $P$. chrysosporium selama 30 hari memiliki pengurangan kadar hemiselulosa sebesar $25 \%$.

Aplikasi P. chrysosporium pada terentang untuk keperluan bahan baku pulp lebih baik bila dibandingkan dengan hasil penelitian Istikowati dan Marsoem (2006), Pujirahayu dan Marsoem (2009), Widjaya, Adriyani, dan Pratami (2003) pada kayu sengon maupun randu. Hal ini dikarenakan persentase kehilangan lignin dan peningkatan kadar $\alpha$-selulosa lebih besar bila dibandingkan kayu sengon dan randu. Selain disebabkan oleh perbedaan jenis kayu juga disebabkan adanya penambahan nutrisi glukosa pada serpih terentang.

\section{Energi Refining}

Proses refening merupakan penguraian serat (selulosa) dari ikatan lignin melalui mekanis. Pada pengolahan pulp semi-mekanis, rerata kebutuhan energi refining dan penghematan energi dapat dilihat pada Tabel 4. Kebutuhan energi refining pada kontrol memiliki nilai sama dengan perlakuan lama inkubasi 3 minggu dan lebih besar bila dibandingkan dengan sampel yang telah diberi 
Tabel 4. Rerata kebutuhan energi refining dan penghematan energi

Table 4. The average of refining energy requirement and energy saving

Lama inkubasi (minggu)

(Incubation period, weeks)
Energi refining

(Refining energy, $\mathrm{kWh} / \mathrm{ton}$ )
Penghematan energi (Energy saving, \%)

\begin{tabular}{ccc}
\hline Kontrol/control & $37,52 \pm 2,57 \mathrm{a}$ & - \\
3 & $37,38 \pm 1,63 \mathrm{a}$ & 0,37 \\
4 & $29,52 \pm 2,26 \mathrm{~b}$ & 21,32 \\
5 & $29,00 \pm 1,67 \mathrm{~b}$ & 22,70 \\
HSD 5\% & 5,09 & - \\
\hline
\end{tabular}

Keterangan (Remarks) : Angka yang diikuti oleh huruf yang sama tidak berbeda nyata pada uji Tukey $\mathrm{p} \leq 0,05$ (Numbers followed by the same letter are non-significantly different, Tukey's test $t \leq 0.05$ )

perlakuan jamur dengan lama inkubasi 4 dan 5 minggu. Hal ini dikarenakan serpih kayu belum diurai oleh jamur sehingga serpih masih keras. Namun pada sampel yang telah diinkubasi jamur selama 4 dan 5 minggu, kebutuhan energinya menjadi semakin sedikit. Adanya perbedaan antara kandungan lignin dan kebutuhan energi refining pada setiap periode inkubasi disebabkan oleh perlakuan $\mathrm{NaOH}$ sebelum refining, meskipun pada taraf konsentrasi yang sama.

Lama inkubasi memiliki korelasi negatif terhadap energi refining, semakin lama waktu inkubasi maka energi yang dibutuhkan untuk proses refining semakin kecil. Sampel yang telah diinkubasi selama 5 minggu hanya membutuhkan energi refining sebesar $29,00 \mathrm{kWh} /$ ton atau turun $22,70 \%$ dari kondisi kontrol. Akan tetapi nilai penghematan energi ini lebih kecil dibandingkan yang dilaporkan Scott et al. (2002) yaitu sebesar 30\%. Perbedaan ini disebabkan oleh perbedaan jenis kayu maupun jenis jamur yang digunakan.

\section{KESIMPULAN}

Penggunaan $P$. chrysosporium pada pengolahan pulp bio-semi-mekanis kayu terentang telah memberikan keuntungan berupa penghematan energi dalam proses refining, walaupun membutuhkan waktu untuk inkubasi. Perlakuan P. chrysosporium dapat menghemat energi refining hingga $22,70 \%$.

\section{DAFTAR PUSTAKA}

Bierman, C.J. (1996). Handbook of pulping and papermaking ( $2^{\text {nd }}$ ed.). California: Academic Press.

Browning, B.L. (1967). Methods of wood chemistry II. New York: Wisconsin Interscience.

Cameron, J.H. (2004). Mechanical pulping. Pulping. Elsevier Ltd.

Fengel, D., \& Wegener, G. (1995). Kimia, ultrastruktur, reaksi-reaksi kayu. Yogyakarta: Gadjah Mada University Press.

Ferraz, A., Parra, C., Freer, J., Baeza, J., \& Rodríguez, J. (2000). Characterization of white zones produced on Pinus radiata wood chips by Ganoderma australe and Ceriporiopsis subvermispora. World Journal of Microbiology and Biotechnology, 16(7), 641-645. http://doi.org/10.1023/A:100898152147 9 .

Gamauf, C., Metz, B., \& Seiboth, B. (2007). Degradation of plant cell wall polymers by fungi. Environmental and Microbial Relationships - The Mycota IV, 325-340.

Haroen, W.K. (2008). Pulp Termo Mekanis (TMP) dan Kimia Termo Mekanis (CTMP) dari limbah batang kenaf. Tropical Wood Science and Technology, 6(2), 69-74.

Hatakka, A., \& Hammel, K.E. (2010). Fungal biodegradation of lignocelluloses. Dalam 
M. Holrichter (Eds). The Mycota X industrial applications $\left(2^{\text {nd }}\right.$ ed.). Berlin: Springer. (Hal. 319-340).

Husaini, A., \& Fisol, F. (2011). Lignocellulolytic enzymes produced by tropical white rot fungi during biopulping of Acacia mangium wood chips. Journal of Biochemical Technology, 3(2), 245-250.

Johansson, L., Hill, J., Gorski, D., \& Axelsson, P. (2011). Improvement of energy efficiency in TMP refining by selective wood disintegration and targeted application of chemicals. Nordic Pulp and Paper Research Journal, 26(01), $031-046$. http://doi.org/10.3183/NPPRJ-2011-2601-p031-046.

Irawati, D., Hayashi, C., Takashima, Y., Wedatama, S., Ishiguri, F., Lizuka, K., Yoshizawa, N., \& Yokota S. (2012). Cultivation of the edible mushroom based substrate made of theree Indonesian commersial plantation species, Falcataria moluccana, Shorea sp., and Tectona grandis. Micologia Aplicada International, 24(2), 33-41.

Istek, A., Sivrikaya, H., Eroglu, H., \& Gulsoy, S.K. (2005). Biodegradation of Abies bornmulleriana (Mattf.) and Fagus orientalis (L.) by the white rot fungus Phanerochaete chrysosporium. International Biodeterioration and Biodegradation, 55(1), 63-67. http://doi.org/10.1016/j.ibiod.2004.07.00 2.

Istikowati, W.T., \& Marsoem, S.N. (2009). Pengaruh inokulasi jamur Phanerochaete chrysosporium Burds terhadap kimia kayu randu (Ceiba pentandra Gaertn). Sains dan Terapan Kimia, 3(2), 144-153.

Kasmani, J.E., Talaeipour, M., Hemmasi, A.H., Mahdavi, S., \& Samarihad, A. (2012). Biochemimechanical pulping of hornbeam chips with Phanerochaete chrysosporium. BioResources, 7(1), 1016-1028.

Kirk, T.K., Burgess, R., \& Koning Jr., J. (1992). Use of fungi in pulping wood: An overview of biopulping research. Frontiers in Industrial Mycology SE - 7, 99-111. http://doi.org/ 10.1007/978-1-4684-7112-0_7.
Koyani, R.D., \& Rajput, K.S. (2014). Light microscopic analysis of Tectona grandis L.f. wood inoculated with Irpex lacteus and Phanerochaete chrysosporium. European Journal of Wood and Wood Products, 72(2), 157-164. http://doi.org/10.1007/s00107-0130763-7.

Mendonca, R., Ferraz, A., Kordsachia, O., \& Koch, G. (2004). Cellular UVmicrospectrophotometric investigations on pine wood (Pinus taeda and Pinus elliottii) delignification during biopulping with Ceriporiopsis subvermispora (Pilat) Gilbn. \& Ryv. and alkaline sulfite/anthraquinone treatment. Wood Science and Technology, 38(7), 567-575. http://doi.org/10.1007/s00226004-0252-6.

Pertiwi, Y.A.B. (2014). Sifat keawetan alami, pencuacaan, dan efektifitas bahan pengawet boron pada kayu jati hutan rakyat. (Tesis Master). Fakultas Kehutanan, Universitas Gadjah Mada, Yogyakarta.

Pujirahayu, N., \& Marsoem, S.N. (2006). Efisiensi pemasakan bio-kraft pulp kayu sengon dengan jamur Phanerochaete chrysosporium. Agro Sains, 19(2), 201-209.

Raphy, K.M.M., Anoop, E.V., Aruna, P., Sheena, V.V., \& Ajayghosh, V. (2011). Provenancevariation in wood chemical properties of Acacia mangium Willd. and Acacia auriculiformis Cunn., grown in a wet humid site in Thrissur district of Kerala, South India. Journal Indian Academy Wood Science, 8(2), 120-123.

Samariha, A. (2011). Effect of altitude on growth rate and physical properties of hornbeam wood (case study in Mashelak forest of Iran). World Applied Sciences Journal, 13(9), 2057-2059.

Scott, G.M, Akhtar, M., Swaney, R.E., \& Houtman, C.J. (2002). Recent developments in biopulping technology at Madison. WI. Dalam Viikari \& R. Lantto (Eds.). Biotechnology in the pulp and paper Industry, Elsevier Science B.V. (Hal. 61-71).

Singh, D., \& Chen, S. (2008). The white-rot fungus Phanerochaete chrysosporium: conditions for 
the production of lignin-degrading enzymes, Applied Microbiology and Biotechnology, 81, 399-417. http://doi.org/10.1007/s00253-0081706-9

Standar Nasional Indonesia (SNI). (1989). Cara uji kadar selulosa alfa, beta dan gamma dalam pulp kayu (SNI 14-0444-1989). Badan Standardisasi Nasional.

Standar Nasional Indonesia (SNI). (2008). Puाp dan kayu - Cara uji kadar lignin (Metode Klason) (SNI 0492-2008). Badan Standardisasi Nasional.

Talaeipour, M., Hemmasi, A.H., Kasmani, J. E., Mirshokraie, S. A., \& Khademieslam, H. (2010). Effects of fungal treatment on structural and chemical features of hornbeam chips. BioResources, 5(1), 477-487.

Widjaya, A., Adriyani, S., \& Pratami, A.A. (2000). Study of biodelignification on sengon and pine using white rot fungus Phanerochaete chrysosporium for develoment of pulp and paper industries in Indonesia. Diakses dari http://www.digilib.its.ac.id., 12 November 2003.

Yang, Q., Zhan, H., Wang, S., \& Fu, S. (2008). Biomodification of Eucalyptus chemithermomechanical pulp. Frontiers of Chemical Engieering in China, 2(1), 28-33. http://doi.org/10.1007/s11705-0080007-2. 